\title{
Performance and carcass characteristics of feedlot-finished Zebu cattle in different feeding systems
}

\section{Desempenho e características da carcaça de bovinos anelorados terminados em diferentes sistemas de alimentação}

\author{
Joaquim José de Paula Neto ${ }^{1 *}$; Emerson Alexandrino ${ }^{2}$; Wagner Soares da Costa \\ Junior $^{1}$; José Messias de Rezende ${ }^{3}$; André Augusto Marinho Silva ${ }^{3}$; \\ Jonahtan Chaves Melo ${ }^{4}$
}

\begin{abstract}
The performance and characteristics of 18 carcasses of feedlot-finished Zebu cattle were evaluated over 93 days in confinement or semi-confinement systems. In the semi-confinement system, two strategies of pasture deferral were adopted, 40 days (40DD) and 80 days (80DD). The feed of animals in confinement was composed of $24 \%$ of grass silage Urochloa spp. and $76 \%$ concentrate, on dry matter, freely supplied twice daily. Grazing animals received $4 \mathrm{~kg}$ of animal concentrate per day. The final fasting weight of the animals in confinement $(534.92 \mathrm{~kg}$ ) was higher than that of animals semi-confined in 40DD (475.33 $\mathrm{kg})$ and $80 \mathrm{DD}(460.67 \mathrm{~kg})$ pastures, because of the higher daily weight gain ( $1.37 \mathrm{vs} .0 .82$ and $0.64 \mathrm{~kg}$, respectively). Feedlot-finished animals had a greater carcass gain $\left(0.91 \mathrm{~kg}\right.$ animal $\left.{ }^{-1} \mathrm{day}^{-1}\right)$, resulting in a higher carcass weight $(296.47 \mathrm{~kg})$, higher thickness of external fat $(5.42 \mathrm{~mm})$, weight and percentage of side cut (17.88 kg and $12.20 \%$ ), and weight and percentage of fat in the carcass (74.50 kg and $25.22 \%)$. However, no difference was observed for the metric and developmental characteristics of the carcass, which allowed good quality carcasses to be obtained, independent of the strategies evaluated. Feedlotfinished Zebu cattle provide heavier and bulky carcasses, leading to higher revenue per marketed carcass. Key words: Confinement. Fat. Gain yield. Semi-confinement. Trimming.
\end{abstract}

\section{Resumo}

Avaliou-se o desempenho e as características da carcaça de 18 bovinos anelorados terminados durante 93 dias em confinamento ou semiconfinamento. No semiconfinamento foram adotadas duas estratégias de diferimento da pastagem, com 40 dias (40DD) e 80 dias (80DD). A ração dos animais confinados foi composta de $24 \%$ de silagem de capim Urochloa spp. e $76 \%$ de concentrado, na matéria seca, fornecida à vontade duas vezes ao dia, enquanto que os animais em pastejo receberam $4 \mathrm{~kg}$ de concentrado animal ${ }^{-1}$ $\mathrm{dia}^{-1}$. O peso final em jejum dos animais confinados $(534,92 \mathrm{~kg})$ foi superior aos semiconfinados em pastagem 40DD (475,33 kg) e 80DD (460,67 kg), devido ao maior ganho de peso diário (1,37 vs. 0,82 e $0,64 \mathrm{~kg}$, respectivamente). Animais terminados em confinamento tiveram maior ganho de carcaça $(0,91$

1 Drs. em Ciência Animal Tropical, Universidade Federal do Tocantins, UFT, Araguaína, TO, Brasil. E-mail: jneto@zootecnista. com.br; wjr_zootecnia@hotmail.com

2 Prof. Dr., Colegiado de Zootecnia, UFT, Araguaína, TO, Brasil. E-mail: e_alexandrino@yahoo.com.br

3 Discentes, Curso de Doutorado, Programa de Pós-Graduação em Ciência Animal Tropical, UFT, Araguaína, TO, Brasil. E-mail: messyas10@hotmail.com; andre_augusto89@hotmail.com

4 Prof. Dr., Centro de Ciências Agrárias e Ambientais, Faculdade Católica do Tocantins, FACTO, Palmas, TO, Brasil. E-mail: jonahtan.melo@catolica-to.edu.br

* Author for correspondence 
$\mathrm{kg}$ animal ${ }^{-1}$ dia $\left.^{-1}\right)$, determinando maior peso de carcaça quente $(296,47 \mathrm{~kg})$, com melhor acabamento de gordura $(5,42 \mathrm{~mm})$, peso e porcentagem do costilhar $(17,88 \mathrm{~kg}$ e $12,20 \%)$ e peso e porcentagem de gordura na carcaça $(74,50 \mathrm{~kg}$ e $25,22 \%)$. Contudo, não se observou diferença para as características métricas e de desenvolvimento da carcaça, possibilitando obter carcaças com boa qualidade independente das estratégias avaliadas. A terminação de bovinos anelorados em confinamento proporciona carcaças mais pesadas e com melhor acabamento, permitindo maior receita por carcaça comercializada.

Palavras-chave: Confinamento. Gordura. Rendimento do ganho. Semiconfinamento. Toalete.

\section{Introduction}

In Brazil, beef consumption, exports, and beef demand are expected to be higher than supply over the coming years, generating economic imbalance (BRASIL, 2014). To meet this growing demand, the production of younger animals may be an alternative to increase Brazilian productive indexes, which are still far below their potential.

Improving the nutritional condition of cattle in Brazil has helped to reduce the age at slaughter, whereby supplementation with concentrated products is a determining factor, particularly when the pasture does not meet the requirements of the animals. The finishing phase of the animal is the most important; depending on the strategy used, the animals may remain within the production system for a long or short period, with the producer being responsible for the decision.

In recent years, feedlot finishing has been widely used because it provides greater weight gain, and less time is required to finish animals with heavier carcasses. Menezes et al. (2010) evaluated Devon steers finished in different systems, and observed that animals finishing in confinement and in cultivated pasture presented higher daily weight gain, with better quality carcasses, than those finished in tropical pasture.

However, Macitelli et al. (2007) evaluated different forage in the finishing of crossbred Holstein-Zebu cattle, and observed no difference in performance between those fed on sugarcane confinement and those fed on Marandu grass pasture. In that study, both groups received 1\% live weight daily in concentrate, demonstrating the importance of forage quality at this stage.
Thus, when the semi-confinement system is chosen with the aim of reducing production costs, it is necessary to produce forage of a sufficient quantity and quality to finish the young animals, even in the dry season. At this point, the deferment period may determine the morphological composition of the pasture (SANTOS et al., 2010), and therefore, influence animal performance.

Therefore, the objective of this study was to evaluate the performance and characteristics of carcasses of feedlot-finished Zebu cattle in confinement or semi-confinement systems, under different pasture deferral strategies.

\section{Material and Methods}

The study was conducted from May 25 to September 9, 2013, with 14 days of adaptation and 93 days of evaluation at NEPRAL - Center for Studies of Ruminant Production in the Legal Amazon, Federal University of Tocantins (UFT), School of Veterinary Medicine and Animal Science, Araguaína Campus, S $07^{\circ} 12^{\prime} 28^{\prime \prime}$ and W 48 12 '26', according to the ethical standards approved by the Animal Research Ethics Committee of the same institution, under protocol no. 23101.000785/2.014-91.

The experimental design was completely randomized, with three treatments and six replicates (animals). Eighteen contemporary Nelore breed steers were used. Animals were weaned at 8 months of age and raised for 10 months in Urochloa (syn. Brachiaria) hybrid "Mulato II" (grass-HD364), with gains close to $600 \mathrm{~g}^{\text {animal }}{ }^{-1}$ day $^{-1}$ only with mineral supplementation. At the beginning of the experiment, 20-month-old animals presented 
$402.33 \pm 33.70 \mathrm{~kg}$ of body weight. These animals were randomly distributed into three lots with homogeneous weights, and finished in different feeding systems, two semi-confinement strategies, with 40 or 80 days of pasture deferral, and confinement.

To establish different pasture conditions, pastures were fertilized with $40 \mathrm{~kg} \mathrm{ha}^{-1}$ of $\mathrm{N}$ and $\mathrm{K}_{2} \mathrm{O}$, formulated at 20:00:20, and then sealed. One remained in deferral for 40 days (from 04/15/2013 to $05 / 25 / 2013$ ), termed pasture 40DD, and another remained in deferral for 80 days $(03 / 06 / 2013$ to 05/25/2013), and was termed pasture 80DD. Pasture area 40DD comprised 2 ha of Urochloa brizantha "Marandu", and the 80DD pasture comprised 2 ha, of Urochloa hybrid "Mulato II" (grass-HD364), and both contained drinking fountains and collective feeders.

Finished animals in semi-confinement were maintained on grazing, with each animal receiving 4 $\mathrm{kg}$ of concentrate daily at 10:00 am, corresponding to $9.2 \mathrm{~g} \mathrm{~kg}^{-1}$ of body weight on average, in an uncovered trough with double-sided access and a space of $60 \mathrm{~cm}$ per animal. The concentrate supplied was the same as that used for animals in confinement. A continuous grazing system was used, with a capacity of three animals initially available per hectare for grazing; after 45 days of use, the remainder of the area was released.

The forage mass was estimated at the beginning and end of the experiment (Table 1) after determination of canopy height, which acted as a reference for the sampling of all forage contained in a metal structure of $1 \times 0.6 \mathrm{~m}\left(0.6 \mathrm{~m}^{2}\right)$, and located close to the ground. The component material was separated into green leaves, green stem, and dead material, and their respective mass was then determined after drying in an oven at $55^{\circ} \mathrm{C}$ for 72 hours. Simultaneously, grazing simulations were performed to determine the bromatological forage composition for different pasture conditions (Table 2).

Table 1. Dry forage mass and the relative composition of morphological components of the semi-confined area at the beginning and end of the experimental period.

\begin{tabular}{lcccccc}
\hline Items $^{1}$ & Period & Height $(\mathrm{cm})$ & $\mathrm{FM}\left(\mathrm{kg} \mathrm{ha}^{-1}\right)$ & \%LB & $\% \mathrm{~S}$ & $\% \mathrm{SM}$ \\
\hline \multirow{2}{*}{ Pasture 40DD } & Beginning & 34.6 & 6228 & 31.47 & 26.02 & 42.49 \\
& End & 29.0 & 3221 & 6.13 & 29.45 & 64.41 \\
\multirow{2}{*}{ Pasture 80DD } & Beginning & 51.2 & 7422 & 19.02 & 32.46 & 48.50 \\
& End & 37.0 & 3576 & 3.76 & 17.65 & 78.57 \\
\hline
\end{tabular}

${ }^{1}$ Pasture $40 \mathrm{DD}=40$ days deferred pasture; Pasture $80 \mathrm{DD}=80$ days deferred pasture; FM = forage mass; \%LB = percentage of green leaf blade; $\% \mathrm{~S}=$ percentage of green stem; $\% \mathrm{SM}=$ percentage of senescence material.

Table 2. Chemical composition (based on dry matter) of dietary and pasture ingredients by grazing simulation.

\begin{tabular}{lcccc}
\hline \multirow{2}{*}{ Ingredients $^{1}$} & \multicolumn{3}{c}{ Variables } \\
\cline { 2 - 5 } & ${ }^{*} \mathrm{DM}, \mathrm{g} \mathrm{kg}^{-1}$ & ${ }^{*} \mathrm{CP}, \mathrm{g} \mathrm{kg}^{-1}$ & ${ }^{+} \mathrm{TDN}, \mathrm{g} \mathrm{kg}^{-1}$ & ${ }^{\text {\# }} \mathrm{NDF}, \mathrm{g} \mathrm{kg}^{-1}$ \\
\hline Grass silage & 293.9 & 43.9 & 555.9 & 797.2 \\
Concentrate & 856.1 & 169.2 & 789.0 & 177.6 \\
Pasture 40DD & 469.6 & 72.5 & 603.0 & 727.0 \\
Pasture 80DD & 546.0 & 47.9 & 622.6 & 695.0 \\
\hline
\end{tabular}

${ }^{1}$ Pasture $40 \mathrm{DD}=40$ days deferred pasture; Pasture $80 \mathrm{DD}=80$ days deferred pasture; $\mathrm{DM}=$ dry matter; $\mathrm{CP}=$ crude protein; TDN $=$ total digestible nutrients; $\mathrm{NDF}=$ neutral detergent fiber

*AOAC (1995), ${ }^{+}$Weiss et al. (1992), "Van Soest et al. (1991). 
The animals in confinement were kept in individual bays of $11 \mathrm{~m}^{2}(2 \times 5.5 \mathrm{~m})$, partially covered with fiber cement tiles and concreted (6 $\mathrm{m}^{2}$ ), with individual feeders and drinking fountains shared between two bays. Feeding consisted of Urochloa spp. and concentrate, in a ratio of 24:76, respectively, supplied freely twice a day (08:30 and 14:00), with the concentrate mixed manually with the forage in the trough at the time of feeding. Each morning, before provision, leftovers from the previous day were removed and weighed to adjust the food supply; leftovers between 5 and $8 \%$ of the total amount offered were left. Weekly samples representing the forage and the ingredients of the concentrate were collected, and the pastures were sampled to simulate grazing at the beginning and end of the finishing period. These samples were analyzed in the UFT bromatology laboratory, and data are presented in Table 2.

The feed for animals in confinement contained an average $140.4 \mathrm{~g} \mathrm{~kg}^{-1}$ of crude protein and $600.3 \mathrm{~g}$ $\mathrm{kg}^{-1}$ of total digestible nutrients, which was balanced for a weight gain of $1.4 \mathrm{~kg} \mathrm{day}^{-1}$, with an estimated consumption of $2.4 \mathrm{~kg}$ of DM $100 \mathrm{~kg} \mathrm{PV}^{-1}$ (NRC, 1996). The concentrate used for all feeding systems consisted of ground grain sorghum (88.56\%), soybean meal $(8.14 \%)$, calcitic limestone $(1.2 \%)$, cattle urea $(1.2 \%)$, ammonium sulfate $(0.14 \%)$, common salt $(0.24 \%)$, and mineral premix $(0.52 \%)$ with the addition of monensin at $0.77 \mathrm{~g} \mathrm{~kg}^{-1}$ of the product.

The animals were weighed individually at the beginning of the fasting experiment, and at 28day intervals, without fasting, in order to monitor performance. After 93 days of evaluation, when the semi-confined lots reached the minimum weight required by the region's slaughterhouses $(480 \mathrm{~kg}$ ), the animals were fasted with solids and liquids for 16 hours, weighed to obtain the final fasted weight, and sent to slaughter in a commercial slaughterhouse with the Federal Inspection Service located $60 \mathrm{~km}$ from the experimental area, following the normal process of the establishment.
The daily carcass gain (CG) was determined by the difference between the warm carcass weight and the initial carcass weight, divided by the evaluation period. For the calculations, the initial carcass weight was estimated to be $52 \%$ yield. The gain yield (GY) was also calculated as described by Pazdiora et al. (2013) and Moretti (2015), and expressed by the relationship between daily CG and daily weight gain.

After slaughtering, the carcasses were divided in half and identified, and the fat scraps obtained during carcass cleaning (the so-called 'trim'), were collected and weighed. At the end of the slaughter line, the carcasses were weighed to determine the warm carcass weight, and then washed and cooled for 24 hours between 0 and $2^{\circ} \mathrm{C}$. After cooling, the half-carcasses were weighed again to determine the cold carcass weight and subjectively evaluated for physiological maturity and carcass conformation, as described by Müller (1987). The carcass yield was determined by the relationship between the carcass weight and the final fasting weight.

In the right-half carcass, carcass length (from the medial cranial edge of the first rib and the anterior edge of the pubic bone), thickness of the topside (measured between the lateral and medial sides of the topside portion), length (from the radio-carpal joint to the end of the olecranon), and arm perimeter (involving the middle part of the radius-ulna and the muscles covering the region) were measured, as described by Cruz et al. (2015).

Furthermore, in the half-carcass, a cut was made between the 12th and 13th ribs, exposing the longissimus dorsi muscle, where its contour was drawn in vegetable paper to determine its area $\left(\mathrm{cm}^{2}\right)$ (ALD), using the software AutoCad ${ }^{\circledR}$. The thickness of subcutaneous fat was also measured around the longissimus dorsi muscle, and determined by the arithmetic mean of three observations. To determine the physical composition of the carcass, the percentages of muscle, fat, and bone were determined, following the methodology described 
by Hankins and Howe (1946) and adapted by Müller et al. (1973).

The left half of the carcass was separated into primary cuts, with the forequarter separated from the pistol cut and short ribs between the $5_{\text {th }}$ and $6_{\text {th }}$ ribs, which included neck, shoulder, arm, and five ribs. Through the rib cut at $22 \mathrm{~cm}$ of the vertebral column, the pistol cut was separated from the short ribs, which included the ribs from the sixth rib onward, plus the abdominal muscles. After that, the primary cuts were weighed, and the relative weight of the half carcass was determined.

Data were analyzed for normality and homogeneity of variance, and after satisfying these assumptions, the data were submitted to analysis of variance and the averages were compared by Tukey's test ( $\alpha=5 \%$ ) using SAS Statistical Software (SAS, 2001). The mathematical model used was: $\Upsilon i j=\mu$
$+\mathrm{T} i+$ E $i j$, where: $\Upsilon i j=$ dependent variables; $\mu=$ overall average of all observations; $\mathrm{T} i=$ treatment effect of order " $i$ ", and $E i j=$ residual random error. Correlations between the dependent variables were determined by calculating the Pearson's correlation coefficients.

\section{Results and Discussion}

The final fasting weight (FW) of feedlot-finished animals was higher $(\mathrm{P}<0.05)$ than that of semiconfined animals, with no difference observed between the pasture conditions (Table 3). The 14\% increase in FW represented an average additional 60 $\mathrm{kg}$ in the total weight gain (TWG) for the animals in confinement during the same feeding period, due to their high average daily weight gain (ADG), at an average of $1.37 \mathrm{~kg}$ animal ${ }^{-1}$ day $^{-1}$.

Table 3. Weight, performance, and carcass characteristics of feedlot-finished Zebu cattle maintained under different feeding systems.

\begin{tabular}{lccccc}
\hline \multirow{2}{*}{ Items $^{1}$} & \multicolumn{3}{c}{ Feeding systems } & \multirow{2}{*}{ CV $(\%)$} & P-value \\
\cline { 2 - 4 } & Confinement & Pasture 40DD & Pasture 80DD & & - \\
IW, kg & 407.00 & 399.00 & 401.00 & - & 0.012 \\
FW, kg & $534.92^{\mathrm{A}}$ & $475.33^{\mathrm{B}}$ & $460.67^{\mathrm{B}}$ & 8.13 & 0.001 \\
TWG, kg & $127.92^{\mathrm{A}}$ & $76.33^{\mathrm{B}}$ & $59.67^{\mathrm{B}}$ & 18.62 & 0.001 \\
ADG, kg & $1.37^{\mathrm{A}}$ & $0.82^{\mathrm{B}}$ & $0.64^{\mathrm{B}}$ & 18.53 & 0.018 \\
WCW, kg & $296.47^{\mathrm{A}}$ & $261.03^{\mathrm{B}}$ & $260.38^{\mathrm{B}}$ & 8.05 & 0.186 \\
WCY, \% & $55.42^{\mathrm{A}}$ & $54.91^{\mathrm{A}}$ & $56.52^{\mathrm{A}}$ & 2.71 & 0.001 \\
CG, kg dia & $0.91^{\mathrm{A}}$ & $0.58^{\mathrm{B}}$ & $0.56^{\mathrm{B}}$ & 18.11 & 0.002 \\
GY, g kg & $664.23^{\mathrm{B}}$ & $707.31^{\mathrm{B}}$ & $875.00^{\mathrm{A}}$ & 12.13 & 0.001 \\
TRI, kg & $14.64^{\mathrm{A}}$ & $10.03^{\mathrm{B}}$ & $9.21^{\mathrm{B}}$ & 16.96 & 0.018 \\
CCW, kg & $293.13^{\mathrm{A}}$ & $258.30^{\mathrm{B}}$ & $258.67^{\mathrm{B}}$ & 8.07 & 0.110 \\
CCY, \% & $54.80^{\mathrm{A}}$ & $54.35^{\mathrm{A}}$ & $56.15^{\mathrm{A}}$ & 2.65 & 0.827 \\
DL, \% & $1.12^{\mathrm{A}}$ & $1.04^{\mathrm{A}}$ & $0.66^{\mathrm{A}}$ & 80.88 & 0.001 \\
SFT, mm & $5.42^{\mathrm{A}}$ & $2.67^{\mathrm{B}}$ & $2.87^{\mathrm{B}}$ & 20.95 & \\
\hline
\end{tabular}

${ }^{1} \mathrm{IW}=$ initial fasting weight; FW = final fasting weight; TWG = total weight gain; ADG = average daily weight gain; WCW = warm carcass weight; WCY = warm carcass yield; $\mathrm{CG}=$ carcass gain; $\mathrm{GY}=$ gain yield; $\mathrm{TRI}=$ trimming; $\mathrm{CCW}=$ cold carcass weight; $\mathrm{CCY}=$ cold carcass yield; $\mathrm{DL}=$ drip loss; SFT $=$ subcutaneous fat thickness.

${ }^{\mathrm{A}, \mathrm{B}}$ Same letters in a row do not differ $(\mathrm{P}>0.05)$ by the Tukey's test. $\mathrm{CV}=$ coefficient of variation $(\%)$. 
The ADG of animals in confinement was higher $(\mathrm{P}<0.05)$ than that of grazing animals (Table 3), which is consistent with the findings of Menezes et al. (2010) and Olmedo et al. (2011). Certainly, the low quality of the forage used in the confinement, with lower nutritional quality compared to the pastures (Table 2), did not determine animal performance. This was because the low inclusion of the forage in diet (24\%) allowed most of the digestible energy to be obtained from the concentrate, since the confined animals consumed $10 \mathrm{~kg}$ of animal concentrate ${ }^{-1}$ day $^{-1}$; however, this was limited to $4 \mathrm{~kg}_{\text {animal }}{ }^{-1}$ day $^{-1}$ under semi-confined strategies.

Vaz et al. (2008) also attributed the lower performance of the grazing animals to the higher energy demand for forage seizure, even if the pasture area is small. Although no difference in ADG was observed among semi-confined animals, there was an additional trend of $180 \mathrm{~g}$ of animal ${ }^{-1}$ day $^{-1}$ for animals under 40DD pasture, possibly reflecting grazing management, whereby the shorter sealing period guaranteed a higher proportion of leaf blades in the canopy structure (Table 1). This facilitated forage intake of better quality (Table 2), which mainly affected the size and content of the gastrointestinal tract, since the carcass gain (CG) of the semi-confined animals was similar (on average, $0.57 \mathrm{~kg} \mathrm{day}^{-1}$ ). This was guaranteed by the high numerical value for warm carcass yield (WCY), although no significant difference was found $(\mathrm{P}>0.05)$. Therefore, caution should be taken when referring to the weight gain obtained using a balance, especially in situations with higher concentrate supply, since it may not reflect the carcass gain.

Although the longer deferment period of the 80DD pasture guaranteed $20 \%$ more forage mass (Table 2), this management is not justified, since it did not lead to improvement in the CG. Furthermore, in addition to not guaranteeing high stocking during fattening, this management increased the unproductive period of grazing with the 40-day depreciation caused by the deferral over the water period, depending on the system's productive indicators. For example, a stocking of four animals $\mathrm{ha}^{-1}$ with ADG of $800 \mathrm{~g}_{\text {animal }}{ }^{-1}$ day $^{-1}$, would not be incorporated into the $128 \mathrm{~kg} \mathrm{ha}^{-1}$ system.

The amount of carcass contained in the daily gain, as defined by yield gain (MORETTI, 2015) for confined animals, was lower than that for semi-confined animals (664.23 vs. $791.15 \mathrm{~g} \mathrm{~kg}$ 1) (Table 3). This is because the finished animals under grazing conditions received $4 \mathrm{~kg}$ of day $^{-1}$ of concentrate. This probably increased the passage rate, due to the selection of forage parts that were more nutritive and with greater digestibility, leading to a lower content and weight of the gastrointestinal tract.

Of note, regardless of the strategy used, the weight of animal carcasses was higher than the minimum required by the slaughterhouses of the region $(240 \mathrm{~kg})$, even with semi-confined animals presenting FW lower than $480 \mathrm{~kg}$. This condition was reached before the high WCY, with an average of $55.61 \%$, with no difference observed $(\mathrm{P}>0.05)$ between feeding strategies. These results are consistent with those of Macitelli et al. (2007), who evaluated different forages in the finishing of crossbred Holstein-Zebu cattle, and reported no difference in WCY. Similar results were obtained by Menezes et al. (2010), when evaluating the finishing of super-young steers of the Devon breed under different feeding systems. According to Ferreira et al. (2009), the number of fasting hours before slaughter can also influence carcass yield, allowing equality in the emptying of the gastrointestinal tract.

The weight of the trim (Table 3) from the fat scraps obtained during carcass cleaning was approximately $50 \%$ higher $(\mathrm{P}<0.05)$ for the confined animals compared with the animals finished in semi-confinement (14.64 vs $9.62 \mathrm{~kg}$ ), with no difference $(\mathrm{P}>0.05)$ observed between pasture deferral strategies. This increase in trim fat deposition may be associated with a higher rate of weight gain in confined animals (1.37 vs. $0.73 \mathrm{~kg}$ day $^{-1}$ ), as shown by the correlation between trim and 
$\operatorname{ADG}(\mathrm{r}=0.785 ; \mathrm{P}<0.001)$; this was attributed to the higher energy consumption, as discussed above.

A negative correlation was found between WCY and trim $(\mathrm{r}=-0.483 ; \mathrm{P}=0.040)$, where excess fat in the carcass impaired yield; this was also observed by Pacheco et al. (2006). According to Pascoal et al. (2011) this is a point of conflict between producers and slaughterhouses, as cleaning can vary in rigidity according to the company's understanding and demand for deboned meat, and as a consequence, it generates lower profitability per marketed animal.

Cold carcass weight $(\mathrm{CCW})$ remained higher $(\mathrm{P}<0.05)$ for confined animals, with no difference observed $(\mathrm{P}>0.05)$ in cold carcass yield (CCY). This was attributed to the lack of variation in the drip loss (DL) between the feeding systems, with an average of $0.94 \%$. These DL values can be considered inferior to those reported previously (OLMEDO et al., 2011; CRUZ et al., 2015), which in view of the high coefficient of variation $(\mathrm{CV}=80.88)$ can be attributed to problems during the weighing process, or in the calibration of the scales, since the scales were in different places inside the slaughtering plant.

According to Müller (1987), weight loss during cooling is associated with the fat cover thickness of the carcass. However, the present data did not reveal any correlation between these variables $(\mathrm{r}=0.088$; $\mathrm{P}=0.726$ ). The animals in confinement had an average of $5.42 \mathrm{~mm}$ subcutaneous fat thickness (SFT), which was higher $(\mathrm{P}<0.05)$ than that found for animals in semi-confinement, and did not differ $(\mathrm{P}>0.05)$ among themselves, with an average value of $2.77 \mathrm{~mm}$.

The carcasses of the semi-confined animals were slightly lower than the standards considered adequate by the slaughterhouses, with $3 \mathrm{~mm}$ fat. These values are satisfactory since Nelore animals finished in tropical grass with only mineral supplement can present fat less than 2-mm thick (BARONI et al., 2010). This shows the importance of high-protein supplementation during the finishing phase, allowing a better finishing of the carcass.

From the absolute weights of the primal cuts relative to the cold half-carcass (Table 4), only the pistol cut weight was not modified $(\mathrm{P}>0.05)$ by the feeding strategies, although that of the animals in confinement was $5.6 \mathrm{~kg}$ higher. Conversely, the forequarter and short ribs weights were higher $(\mathrm{P}<0.05)$ for animals finished in confinement, which justifies the higher weight of the cold carcass.

Table 4. Primal cuts expressed in absolute values $(\mathrm{kg})$ and relative (\%) to the half-carcass of feedlot-finished Zebu cattle maintained under different feeding systems.

\begin{tabular}{lcccccc}
\hline \multirow{2}{*}{ Items } & & \multicolumn{3}{c}{ Feeding systems } & \multirow{2}{*}{ CV (\%) } & \multirow{2}{*}{ P-value } \\
\cline { 3 - 5 } & & Confinement & Pasture 40DD & Pasture 80DD & & 0.029 \\
Forequarter & $\mathrm{kg}$ & $61.57^{\mathrm{A}}$ & $54.37^{\mathrm{B}}$ & $54.53^{\mathrm{B}}$ & 8.83 & 0.029 \\
Forequarter & $\%$ & $42.01^{\mathrm{A}}$ & $42.10^{\mathrm{A}}$ & $42.16^{\mathrm{A}}$ & 2.74 & 0.954 \\
Pistol cut & $\mathrm{kg}$ & $67.12^{\mathrm{A}}$ & $61.42^{\mathrm{A}}$ & $61.65^{\mathrm{A}}$ & 8.05 & 0.107 \\
Pistol cut & $\%$ & $45.79^{\mathrm{B}}$ & $47.55^{\mathrm{A}}$ & $47.67^{\mathrm{A}}$ & 2.25 & 0.012 \\
Short ribs & $\mathrm{kg}$ & $17.88^{\mathrm{A}}$ & $13.37^{\mathrm{B}}$ & $13.15^{\mathrm{B}}$ & 9.17 & 0.001 \\
Short ribs & $\%$ & $12.20^{\mathrm{A}}$ & $10.35^{\mathrm{B}}$ & $10.17^{\mathrm{B}}$ & 4.63 & 0.001 \\
\hline
\end{tabular}

${ }^{\mathrm{A}, \mathrm{B}}$ Same letters in a row do not differ $(\mathrm{P}>0.05)$ by the Tukey's test. $\mathrm{CV}=$ coefficient of variation (\%).

Regarding the relative proportions of the primal cuts, the forequarter remained unchanged $(\mathrm{P}>0.05)$, with an average of $42.09 \%$, similar to the results found by Freitas et al. (2008) in Nelore cattle finished in confinement and slaughtered at 22 months of age. The percentage of pistol cut was 
lower for animals in confinement $(\mathrm{P}<0.05)$, with no difference between those under semi-confinement strategies, which may be attributed to the higher proportion of the short ribs, demonstrated by the high and negative correlation between these variables $(\mathrm{r}=-0.601, \mathrm{P}=0.008)$.

Arboitte et al. (2004) evaluated Nelore-Charolais crossbred animals confined to different slaughter weights, and observed a decrease in the percentage of pistol cut and an increase in the percentage of short ribs, with an increase in weight due to fat deposition in this region.

The absolute bone and muscle weights did not differ $(\mathrm{P}>0.05)$ between animals in the different feeding systems, demonstrating the same muscle:bone ratio (MBR) (Table 5). Their relative proportions, however, were lower in the animals in confinement, with $13.82 \%$ of bone and $60.99 \%$ of muscle, whereas among animals under semiconfinement strategies, these values did not differ, with averages of 15.45 and $66.06 \%$ for bone and muscle, respectively.

Table 5. Physical composition of the carcass according to the feeding system.

\begin{tabular}{|c|c|c|c|c|c|c|}
\hline \multirow{2}{*}{ Items } & & \multicolumn{3}{|c|}{ Feeding systems } & \multirow{2}{*}{ CV (\%) } & \multirow{2}{*}{ P-value } \\
\hline & & Confinement & Pasture 40DD & Pasture 80DD & & \\
\hline Bone & $\mathrm{kg}$ & $40.78^{\mathrm{A}}$ & $39.68^{\mathrm{A}}$ & $40.46^{\mathrm{A}}$ & 8.38 & 0.847 \\
\hline Bone & $\%$ & $13.82^{\mathrm{B}}$ & $15.35^{\mathrm{A}}$ & $15.56^{\mathrm{A}}$ & 4.69 & 0.001 \\
\hline Muscle & $\mathrm{kg}$ & $179.93^{\mathrm{A}}$ & $170.31^{\mathrm{A}}$ & $172.65^{\mathrm{A}}$ & 8.42 & 0.512 \\
\hline Muscle & $\%$ & $60.99^{\mathrm{B}}$ & $65.60^{\mathrm{A}}$ & $66.52^{\mathrm{A}}$ & 2.69 & 0.001 \\
\hline Fat & $\mathrm{kg}$ & $74.50^{\mathrm{A}}$ & $49.35^{\mathrm{B}}$ & $46.59^{\mathrm{B}}$ & 12.16 & 0.001 \\
\hline Fat & $\%$ & $25.22^{\mathrm{A}}$ & $19.06^{\mathrm{B}}$ & $17.93^{\mathrm{B}}$ & 7.53 & 0.001 \\
\hline $\mathrm{MBR}^{1}$ & & $4.41^{\mathrm{A}}$ & $4.29^{\mathrm{A}}$ & $4.28^{\mathrm{A}}$ & 6.31 & 0.656 \\
\hline $\mathrm{MFR}^{2}$ & & $2.44^{\mathrm{B}}$ & $3.45^{\mathrm{A}}$ & $3.73^{\mathrm{A}}$ & 8.76 & 0.001 \\
\hline $\mathrm{EP}: \mathrm{B}^{3}$ & & $6.24^{\mathrm{A}}$ & $5.54^{\mathrm{B}}$ & $5.44^{\mathrm{B}}$ & 5.36 & 0.001 \\
\hline
\end{tabular}

${ }^{1} \mathrm{MBR}=$ muscle:bone ratio; ${ }^{2} \mathrm{MFR}=$ muscle:fat ratio; ${ }^{3} \mathrm{EP}: \mathrm{B}$ = edible portion:bone.

${ }^{\mathrm{A}, \mathrm{B}}$ Same letters in a row do not differ $(\mathrm{P}>0.05)$ by the Tukey's test. $\mathrm{CV}=$ coefficient of variation $(\%)$.

As the bone and muscle ratios were reduced, the fat composition in the carcass increased (Table 5), as shown by the correlations $(\mathrm{r}=-0.699 ; \mathrm{P}=0.001$ and $\mathrm{r}=-0.885 ; \mathrm{P}<0.001$, respectively). Thus, the highest $(\mathrm{P}<0.05)$ absolute weight and proportion of fat in the carcass were observed for the animals in confinement. Santos et al. (2013) evaluated Dutch steers in confinement or grazing receiving $1 \%$ concentrate, and observed a greater weight and percentage of fat in the carcass for the animals in confinement, The authors stated that this was related to the greater energy intake associated with lower physical effort compared with those kept in pasture.
The increase in fat composition caused a lower $(\mathrm{P}<0.05)$ muscle:fat ratio (MFR) in the animals maintained in confinement. However, considering the whole edible portion (muscle and fat), those authors obtained a higher $(\mathrm{P}<0.05)$ edible portion:bone (EP:B), a characteristic desired by the slaughterhouses, due to the higher yield obtained in deboning.

Except for the characteristic area of the longissimus dorsi muscle adjusted for $100 \mathrm{~kg}$ of cold carcass (ALD100), the remaining characteristic that directly reflect muscle expression and carcass development (Table 6) were not altered $(\mathrm{P}>0.05)$ by the feeding systems. 
Although the area of the longissimus dorsi muscle (ALD) was on average 10\% lower for animals maintained in confinement, there was no significant difference $(\mathrm{P}>0.05)$. However, when adjusted for $100 \mathrm{~kg}$ of cold carcass (ALD100), the area was smaller $(\mathrm{P}<0.05)$ for animals under the confined system; this may indicate that muscle growth ceased faster than that in the animals in semi- confinement, which intensifies fat deposition. This is shown by the positive correlation between ALD100 and muscle percentage $(\mathrm{r}=0.714, \mathrm{P}=0.008)$, and the negative correlation between cold carcass weight $(\mathrm{r}=-0.602 ; \mathrm{P}=0.008)$, thickness of subcutaneous fat $(\mathrm{r}=-0.668 ; \mathrm{P}=0.002)$, and fat percentage $(\mathrm{r}=-0.725$; $\mathrm{P}=0.001$ ), showing that heavier carcasses alter their composition for a smaller portion of muscle in the carcass.

Table 6. Quantitative characteristics and measures of carcass development for feedlot-finished steers maintained under different feeding systems.

\begin{tabular}{lccccc}
\hline \multirow{2}{*}{ Items } & \multicolumn{3}{c}{ Feeding systems } & \multirow{2}{*}{ CV (\%) } & P-value \\
\cline { 2 - 5 } & Confinement & Pasture 40DD & Pasture 80DD & & \\
\hline ALD $^{1}, \mathrm{~cm}^{2}$ & $65.24^{\mathrm{A}}$ & $70.46^{\mathrm{A}}$ & $72.12^{\mathrm{A}}$ & 10.65 & 0.272 \\
ALD100, cm $^{2}$ & $22.25^{\mathrm{B}}$ & $27.27^{\mathrm{A}}$ & $27.88^{\mathrm{A}}$ & 10.49 & 0.003 \\
Carcass conformation, points $^{2}$ & $11.00^{\mathrm{A}}$ & $11.17^{\mathrm{A}}$ & $11.50^{\mathrm{A}}$ & 9.29 & 0.705 \\
Physiological maturity, points $^{3}$ & $12.83^{\mathrm{A}}$ & $13.00^{\mathrm{A}}$ & $13.00^{\mathrm{A}}$ & 5.21 & 0.886 \\
Carcass length, cm $_{\text {Arm perimeter, cm }}$ & $145.50^{\mathrm{A}}$ & $142.67^{\mathrm{A}}$ & $140.67^{\mathrm{A}}$ & 3.55 & 0.283 \\
Arm length, cm & $37.92^{\mathrm{A}}$ & $36.50^{\mathrm{A}}$ & $37.67^{\mathrm{A}}$ & 5.44 & 0.455 \\
Thickness topside, cm & $43.83^{\mathrm{A}}$ & $43.58^{\mathrm{A}}$ & $43.00^{\mathrm{A}}$ & 3.14 & 0.568 \\
\hline
\end{tabular}

${ }^{1} \mathrm{ALD}=$ longissimus dorsi muscle area; ALD100 = longissimus dorsi muscle area adjusted for $100 \mathrm{~kg}$ of cold carcass.

${ }^{2}$ 1-3: low 4-6: poor: 7-9: regular; 10-12: good; 13-15: very good; 16-18: superior.

${ }^{3} 1-3:>8$ years of age; 4-6: 5.5-8 years of age; 7-9: 4-5.5 years of age; $10-12: 2.5-4.0$ years of age; $13-15:<2.5$ years of age.

${ }^{\mathrm{A}, \mathrm{B}}$ Same letters in a row do not differ $(\mathrm{P}>0.05)$ by the Tukey's test. $\mathrm{CV}=$ coefficient of variation (\%).

There was no difference $(\mathrm{P}>0.05)$ in carcass conformation, a subjective measure of muscle volume, and this was classified as "good typical" (11 points) and "good plus" (12 points). Even the animals finished in semi-confinement presented carcasses adequate for the requirements of the consumer market, with good muscle expression. This could be compared to that of animals $5 / 8$ Nelore - 3/8 Charolais evaluated by Arboitte et al. (2004), which were castrated and finished in confinement, and presented carcass weights similar to those found in the present experiment.

Maturity values did not differ $(\mathrm{P}>0.05)$, demonstrating that the animals were contemporaneous. Missio et al. (2010) found that increasing the level of concentrate reduces the time of confinement and consequently reduces physiological maturity, a factor not verified in the present study because the strategies involved the same finishing duration (93 days). Santos et al. (2008) evaluated castrated 22-month-old CharolaisNelore mestizos and reported similar values (12.67 points) to those obtained in the present study.

Measurements of carcass length, perimeter and arm length, and topside thickness were not affected $(\mathrm{P}>0.05)$ by the different feeding systems (Table 6). Similarly, Menezes et al. (2010) and Vaz et al. (2008) found no change in the carcass 
measurements of finished animals under different feeding systems; those authors noted that this was associated with the similarity between slaughter and carcass weights. Therefore, even when a difference in WCW was found (Table 3), semi-confined animals presented carcasses with muscle expression and metric measurements compatible with those of animals finished in confinement

Although the animals studied were the same age, those finished in confinement exhibited an average $3.8 \mathrm{~cm}$ greater carcass length (Table 6). Kuss et al. (2005) noted this difference may be related to the greater pressure between ribs due to the increase in fat deposition in the muscles of the region of the ribs, leading to larger carcasses. In fact, the evaluated characteristic was significantly correlated with weight $(\mathrm{r}=0.484, \mathrm{P}=0.040)$ and percentage of ribs ( $\mathrm{r}=0.491, \mathrm{P}=0.038)$, subcutaneous fat thickness $(\mathrm{r}=0.498, \mathrm{P}=0.035)$ and weight $(\mathrm{r}=0.493 ; \mathrm{P}=0.037)$, and percentage of fat in the carcass $(\mathrm{r}=0.504$; $\mathrm{P}=0.032$ ).

Freitas et al. (2008) also found similar arm length measurements $(42.04 \mathrm{~cm})$ in Nelore animals of the same age, but with a lower arm perimeter (33.02), which was possibly related to the lower carcass weight. These characteristics, according to Ferreira et al. (2009), are highly correlated, as observed in the present study $(\mathrm{r}=0.651, \mathrm{P}=0.003)$.

Similarities in the thickness of the topside may be related to the similar conformation of the carcasses, with the posterior muscles presenting the same muscular hypertrophy, since these are usually correlated variables (ARBOITTE et al., 2004). Although no correlation was observed between these variables $(\mathrm{r}=0.188 ; \mathrm{P}=0.473)$, a correlation was found between the thickness of the topside, with the warm carcass weight $(\mathrm{r}=0.490, \mathrm{P}=0.045)$ and muscle weight $(\mathrm{r}=0.497, \mathrm{P}=0.042)$, indicating that heavier carcasses tend to have larger, more bulky muscles.

\section{Conclusion}

Feedlot-finished animals show greater weight and carcass gain, and thus, heavier carcasses, with better quality and higher fat composition than animals finished in semi-confinement. Good quality carcasses can be obtained, regardless of the finishing strategy used, providing the animals are young and ready for slaughter.

\section{Acknowledgments}

To the Federal University of Tocantins for the infrastructure, to CAPES and CNPq for providing financial support and for granting the scholarships.

\section{References}

ARBOITTE, M. Z.; RESTLE, J.; ALVES FILHO, D. C.; PASCOAL, L. P.; PACHECO, P. S.; SOCCAL, D. C. Características da carcaça de novilhos 5/8 Nelore-3/8 Charolês abatidos em diferentes estádios de desenvolvimento. Revista Brasileira de Zootecnia, Viçosa, MG, v. 33, n. 4, p. 969-977, 2004.

ASSOCIATION OF OFFICIAL ANALYTICAL CHEMISTS - AOAC. Official methods of analysis. $16^{\text {th }}$ ed. Arlington: AOAC, 1995. 1025 p.

BARONI, C. E.; LANA, R. P.; MANCIO, A. B.; QUEIROZ, A. C.; SVERZUT, C. B.; MENDONÇA, B. P. C. Desempenho de novilhos suplementados e terminados em pasto, na seca, e avaliação do pasto. Arquivo Brasileiro de Medicina Veterinária e Zootecnia, Belo Horizonte, v. 62, n. 2, p. 373-381, 2010.

BRASIL. Ministério da Agriculta, Pecuária e Abastecimento. Plano mais safra, Assessoria de Gestão Estratégica. Brasília: MAPA/ACS, 2014. 32 p. Disponível em: <http://www.agricultura.gov.br/arq_editor/ MAIS PECUARIA.pdf $>$. Acesso em: 1 jun. 2015.

CRUZ, R. S.; ALEXANDRINO, E.; MISSIO, R. L.; RESTLE, J.; MELO, J. C.; PAULA NETO, J. J.; SILVA, A. A. M.; SILVA, D. P. Níveis de concentrado e farelo do mesocarpo de babaçu sobre as características da carcaça de tourinhos confinados. Bioscience Journal, Uberlândia, v. 31, n. 1, p. 73-86, 2015.

FERREIRA, J. J.; MENEZES, L. F. G.; RESTLE, J.; BRONDANI, I. L.; ALVES FILHO, D. C.; CALLEGARO, A. M. Características de carcaça de vacas de descarte e novilhos mestiços Charolês $\times$ Nelore em 
confinamento sob diferentes frequências de alimentação. Revista Brasileira de Zootecnia, Viçosa, MG, v. 38, n. 10, p. 1974-1982, 2009.

FREITAS, A. K.; RESTLE, J.; PACHECO, P. S.; PADUA, J. T.; LAGE, M. E.; MIYAGI, E. S.; SILVA, G. F. R. Características de carcaças de bovinos Nelore inteiros vs castrados em duas idades, terminados em confinamento. Revista Brasileira de Zootecnia, Viçosa, MG, v. 37, n. 6, p. 1055-1062, 2008.

HANKINS, O. G.; HOWE, P. E. Estimation of the composition of beef carcasses and cuts. Washington: USDA, 1946. 21 p. (Technical Bulletin, 926).

KUSS, F.; RESTLE, J.; BRONDANI, I. L.; PASCOAL, L. L.; MENEZES, L. F. G.; PAZDIORA, R. D.; FREITAS, L. S. Características da carcaça de vacas de descarte de diferentes grupos genéticos terminadas em confinamento com distintos pesos. Revista Brasileira de Zootecnia, Viçosa, MG, v. 34, n. 3, p. 915-925, 2005.

MACITELLI, F.; BERCHIELLI, T. T.; MORAIS, J. A. S.; SILVEIRA, R. N.; CANESIN, R. C. Desempenho e rendimento de carcaça de bovinos mestiços alimentados com diferentes volumosos e fontes protéicas. Revista Brasileira de Zootecnia, Viçosa, MG, v. 36, n. 6, p. 1917 1926, 2007.

MENEZES, L. F. G.; RESTLE, J.; BRONDANI, I. L.; SILVEIRA, M. F.; FREITAS, L. S.; PIZZUTI, L. Â. D. Características da carcaça e da carne de novilhos superjovens da raça Devon terminados em diferentes sistemas de alimentação. Revista Brasileira de Zootecnia, Viçosa, MG, v. 39, n. 3, p. 667-676, 2010.

MISSIO, R. L.; BRONDANI, I. L.; ALVES FILHO, D. C.; RESTLE, J.; ARBOITTE, M. Z.; SEGABINAZZI, L. R. Características da carcaça e da carne de tourinhos terminados em confinamento, recebendo diferentes níveis de concentrado na dieta. Revista Brasileira de Zootecnia, Viçosa, MG, v. 39, n. 7, p. 1610-1617, 2010.

MORETTI, M. H. Estratégias alimentares para a recria e terminação de tourinhos Nelore. 2015. Tese (Doutorado em Zootecnia) - Universidade Estadual Paulista, Faculdade de Ciências Agrárias e Veterinárias, Jaboticabal.

MÜLLER, L. Normas para avaliação de carcaças e concurso de carcaças de novilhos. 2. ed. Santa Maria: UFSM, Imprensa Universitária, 1987. 31 p.

MÜLlER, L.; MAXON, W. E.; PALMER, A. Z. Técnicas para determinar la composición de la canal. In: MEMORIA DE LA ASSOCIACIÓN LATINO AMERICANA DE PRODUCCIÓN ANIMAL, 1973, Guadalajara. Anais... Guadalajara: Associación Latino Americana de Producción Animal, 1973.
NATIONAL RESEARCH COUNCIL - NRC. Nutrient requirements of beef catle. $7^{\text {th }}$ rev. ed. Washington, D.C.: National Academy Press, 1996.

OLMEDO, D. O.; BARCELLOS, J. O. J.; CANELLAS, L. C.; VELHO, M. M. S.; PANIAGUA, P.; HORITÁ, I.; TAROUCO, J. U. Desempenho e características da carcaça de novilhos terminados em pastejo rotacionado ou em confinamento. Arquivo Brasileiro de Medicina Veterinária e Zootecnia, Belo Horizonte, v. 63, n. 2, p. 348-355, 2011.

PACHECO, P. S.; RESTLE, J.; SILVA, J. H. S.; FREITAS, A. K.; ARBOITTE, M, Z.; PADUA, J. T. Relação entre componentes do corpo vazio e rendimentos de carcaça de novilhos de corte. Ciência Animal Brasileira, Goiânia, v. 7, n. 2, p. 107-113, 2006.

PASCOAL, L. L.; VAZ, F. N.; VAZ, R. Z.; RESTLE, J.; PACHECO, P. S.; SANTOS, J. P. A. Relações comerciais entre produtor, indústria e varejo e as implicações na diferenciação e precificação de carne e produtos bovinos não-carcaça. Revista Brasileira de Zootecnia, Viçosa, MG, v. 40, p. 82-92, 2011 Suplemento Especial.

PAZDIORA, R. D.; RESENDE, F. D.; FARIA, M. H.; SIQUEIRA, G. R.; ALMEIDA, G. B. S.; SAMPAIO, R. L.; PACHECO, P. S.; PRIETTO, M. S. R. Animal performance and carcass characteristics of Nellore young bulls fed coated or uncoated urea slaughtered at different weights. Revista Brasileira de Zootecnia, Viçosa, MG, v. 42, n. 4, p. 273-283, 2013.

SANTOS, A. P.; BRONDANI, I. L.; RESTLE, J.; MENEZES, L. F. G.; OLIVEIRA, L.; SILVEIRA, S. R. L. Características quantitativas da carcaça de novilhos jovens e superjovens com peso de abate similares. Ciência Animal Brasileira, Goiânia, v. 9, n. 2, p. 300308, 2008.

SANTOS, M. E. R.; FONSECA, D. M.; GOMES, V. M.; BALBINO, E. M.; MAGALHÃES, M. A. Estrutura do capim-braquiária durante o diferimento da pastagem. Acta Scientiarum, Maringá, v. 32, n. 2, p. 139-145, 2010.

SANTOS, P. V.; PARIS, W.; MENEZES, L. F. G.; VONZ, D.; SILVEIRA, M. F.; TUBIN, J. Carcass physical composition and meat quality of holstein calves, terminated in different finishing systems and slaughter weights. Ciência e Agrotecnologia, Lavras, v. 37, n. 5, p. 443-450, 2013.

STATISTICAL ANALYSIS SYSTEM INSTITUTE SAS. Statistical analysis system user's guide. Version 8.2. Cary: SAS Institute, 2001. CD-ROM.

VAN SOEST, P.; ROBERTSON, J.; LEWIS, B. Methods for dietary fiber, neutral detergent fiber, and nonstarch polysaccharides in relation to animal nutrition. Journal 
of Dairy Science, Champaign, v. 74, n. 10, p. 3583-3597, 1991.

VAZ, F. N.; RESTLE, J.; ARBOITE, M. Z.; PASCOAL, L. L.; ALVES FILHO, D. C.; PACHECO, R. F. Características de carcaça de novilhos Aberdeen Angus terminados em pastagem cultivada ou confinamento. Ciência Animal Brasileira, Goiânia, v. 9, n. 3, p. 590597, 2008.
WEISS, W. P.; CONRAD, H. R.; St. PIERRE, N. R. A theoretically-based model for predicting total digestible nutrient values of forages and concentrates. Animal Feed Science and Technology, Philadelphia, v. 39, n. 1-2, p. 95-110, 1992. 